\title{
THE ROLE OF ASCORBIC ACID IN ZINC OXIDE NANO- PARTICLES INDUCED LUNG TOXICITY IN ADULT MALE ALBINO RATS
}

\author{
Madiha W. Mohamed*, Yara M. El-fakharany*, Nourhan M. Hassan* , Heba M. \\ Elsayed** \\ *Department of forensic medicine and toxicology, ${ }^{* *}$ Histology \&cell biology \\ department, faculty of medicine, Zagazig University, Sharkia governorate, Egypt
}

\begin{abstract}
Zinc oxide nanoparticles (ZnONPs) have been widely used in consumer and industrial products, especially in cosmetics, food additives, photo-electricity and rubber industry. The aim of the work was to evaluate toxic effect of 30 days administration of ZnONPs on lung and the ameliorative role of ascorbic acid in adult male albino rats. They received orally $400 \mathrm{mg} / \mathrm{kg} /$ day of $\mathrm{ZnONPs}$ for 30 days and compared with others received the same dose of ZnONPs $+20 \mathrm{mg} / \mathrm{kg}$ of ascorbic acid regarding GSH, NO, DNA damage and histopathological changes of the lung. Oral administration of 1/20 LD50 of ZnONPs for 30 days led to decrease in serum GSH, increased levels of NO, DNA damage detected by comet assay and histopathological changes in the lung in the form of collapsed alveoli, destruction of interalveolar septa with alveolar dilatation, thick interalveolar septa, heavy infiltration of inflammatory cells and inflammatory exudate. Ascorbic acid administration along with ZnONPs led to attenuation of oxidative stress and pulmonary toxicity induced by ZnONPs, but there was nonsignificant improvement in DNA damage proved by Comet assay. We concluded that ascorbic acid administration along with ZnONPs led to attenuation of oxidative stress and pulmonary toxicity induced by ZnONPs, but there was nonsignificant improvement in DNA damage proved by Comet assay.
\end{abstract}

Keywords: zinc oxide; nanoparticles; lung; ascorbic acid; toxicity

\section{INTRODUCTION}

Zinc oxide nanoparticles (ZnONPs) are new type of highfunctional fine inorganic materials having one dimension that measures 100 nanometers or less (Osmond and McCall, 2010 \& Elsammad et al., 2014). They have been widely used in cosmetics, sun screens, foot-care ointments, antimicrobials, food additives, cancer therapy, over the counter topical products (mouth washes and anti-dandruff shampoos), fungicide, in paints, in photo electricity and rubber industry (Guan et al., 2012).
Oral exposure can occur directly from food, water or orally administered drugs. (Osmond and McCall, 2010). After gut absorption, they are transported to the blood causing adverse biological reactions in several organs. The major sites of interaction with ZnONPs are lung, liver, kidneys and heart (Johnston et al., 2010). The acidic environment of the lung lining fluid result in $\mathrm{ZnONPs}$ dissolution, leading to transient increases in the concentration of $\mathrm{Zn}+^{2}$ ions and local pulmonary toxicity (Vandebriel and De jong, 2012).

Several studies suggested that 
toxicity of $\mathrm{ZnONPs}$ is attributed to disruption of cellular Zinc homeostasis by dissolution of ZnONPs with increased levels of these ions, production of reactive oxygen species (ROS) and reactive nitrogen species (RNS) which lead to oxidative stress, inflammation, DNA damage and cell death (Muserrat et al., 2009; George et al., 2010 \& Kao et al., 2012).

Ascorbic acid (AA) is a naturally occurring organic compound with antioxidant properties attributed to direct radical scavenging, trapping of reactive oxygen species and metal chelation causing reduction in oxidative damage, DNA damage and inflammation (Arrigoni and De Tulio, 2002)

Several invivo and invitro studies proved that AA is a useful agent for attenuating the lung injury caused by increased oxidative stress, preventing protein damage, cytotoxicity and apoptosis (Nemenqani, 2015).

The aim of this study was to investigate the toxicity of administration of ZnONPs for 30 days on the lung and the role of Acorbic acid in amelioration of this toxic effect. For this purpose Biochemical parameters for oxidative stress (reduced glutathione and Nitric oxide) were analysized, lung damage was histopahologically examined and DNA affection was evaluated by Comet assay

\section{MATERIALS AND METHODS}

1. Chemicals: White odorless fine powder of Zinc oxide nanoparticles (ZnONPs) manufactured by Sigma-Aldrisch chemical company, USA were purchased from Sigma-Egypt (Eltayaran st.,Nasr city-Cairo). Its CAS No is 1314-13-2, with particle size $<100 \mathrm{~nm}$ and molecular weight: $81.39 \mathrm{~g} / \mathrm{mol}$. Also white odorless powder (100mg) of pure ascorbic acid were obtained from Elgomhoria Pharmaceuticles Co (Elsawaf st., Zagazig, Egypt).

2. Animals: fifty adult male albino rats weighing between 180-220 $\mathrm{g}$ for each, with average age 60-70 days were used in this study. They were obtained from Animal house of the Faculty of Medicine, Zagazig University. The study was performed at Animal house of the Faculty of medicine, Zagazig University. All animals received human care in compliance with the animal guidelines and ethical regulations in accordance with" The Guide for The Care and Use of Laboratory Animals (Institute of Laboratory Animal Resources et al., 1996).

all animals were left to acclimatize14 days prior to the experimentand were placed in plastic cages free from any source of chemical contamination under controlled conditions with an ambient range of temperature $\left(22 \pm 2^{\circ} \mathrm{c}\right)$, relative humidity $50 \pm 5 \%$ and a $12 \mathrm{~h}$ light-cycle with free access to tap water and balanced food rich in all stuffs important to maintain their health before and during drug administration. Rats were divided into five groups as follow:

Group I:- consisted of 20 rats subdivided equally and randomly into:-

Subgroup Ia (negative control) $\left(\mathrm{n}=10 \_\right)$: each rat received regular diet and tap water for 30 days to measure the basic parameters

Subgroup Ib (positive control) $\underline{(\mathrm{n}=10):}$ animals received $1 \mathrm{ml} / \mathrm{kg} / \mathrm{day}$ distilled water (solvent of zinc oxide and ascorbic acid) orally by gavage for 30 days.

Group II (Ascorbic acid group 
(AA)): $(\mathbf{n = 1 0})$ rats received orally $20 \mathrm{mg} / \mathrm{kg} / \mathrm{day}$ ascorbic acid dissolved in $1 \mathrm{ml}$ distilled water for 30 days (Devi and latha, 2011).

\begin{tabular}{|c|c|}
\hline & (Zinc \\
\hline
\end{tabular}
(ZnONPs): $(\mathbf{n = 1 0})$ :- rats were treated with $(400 \mathrm{mg} / \mathrm{kg} / \mathrm{day})$ of Zinc oxide nanoparticles dissolved in $1 \mathrm{ml}$ distilled water orally by gavage for 30 days. This dose represents $1 / 20$ of the oral LD50 of ZnONPs $\quad(8000 \mathrm{mg} / \mathrm{kg})$ (NIOSH, 2010).

Group IV (ZnONPs + Ascorbic acid treated group (ZnONPs+AA): $\underline{\mathbf{n}=10) \text { :- }}$ rats were treated with $(400 \mathrm{mg} / \mathrm{kg} /$ day $)$ ZnONPs along with ascorbic acid $(20 \mathrm{mg} / \mathrm{kg} /$ day $)$ both dissolved in $1 \mathrm{ml}$ distilled water, gavaged once daily for 30 days.

\section{Biochemical analysis:}

At the end of the experiment; rats were anaesthetized with ether then venous blood samples were collected from the retro-orbital plexuses by means of micro capillary glass tubes under light ether anesthesia (Johnson, 2007). Blood samples were centrifuged to separate the serum and maintained at $\left(-20^{\circ} \mathrm{C}\right)$ to be used for estimation of reduced glutathione (GSH) by the method of Moron et al. (1979) and nitric oxide (NO). according to the method of Montgomery and dymock, (1961).

\section{Histopathological examination and comet assay:}

After blood samples collection rats were sacrificed and the lungs were removed and grossly inspected to assess any gross abnormalities, then divided into two parts: the first part was fixed in $10 \%$ formaline for histopathological examination by light microscope in Histology Department Faculty of Medicine, Zagazig University, according to (Bancroft and Gamble, 2002\& Kiernan, 2001), the second part was put in saline for Comet assay to investigate DNA damage according to the method of Singh et al. (1988) \& Khan et al. (2015) in Animal Reproductive Research Institute (ARRI) of Agricultural Research Centre of Ministry of Agriculture and Land Reclamation (Elharam, Giza)

3. Statstical analysis: All results were expressed as mean \pm standard deviation (SD). For statistical analysis, values among groups were analyzed by one-way analysis of variance (ANOVA). Comparison between experi- mental groups and each other was made byLeast significant difference (LSD).

\section{RESULTS}

\section{Biochemical results:}

Non significant differences regarding mean values of serum GSH and NO among negative control (Ia) $(10.88 \pm 0.69,42.43 \pm 5.44)$, positive control $(\mathrm{Ib})(10.83 \pm 0.72, \quad 43.75 \pm$ 6.11) and ascorbic acid groups(II) $(11.01 \pm 0.75, \quad 44.26 \pm$ 6.75)respectively were detected $(\mathrm{P}>0.05)$ by ANOVA test, so we used negative control group as a standard reference for comparison with other treated groups (table 1). 
Table (1): Statistical Comparison of mean values of biochemical parameters (serum reduced glutathione $(\mathrm{mmol} / \mathrm{dl})$, nitric oxide $(\mu \mathrm{mol} / \mathrm{l})$ and Comet test analysis $(\mathrm{comet}$ tail length $(\mu \mathrm{m})$, Tail DNA \%, Unit tail moment) in negative control (-ve), positive control (+ve) and ascorbic acid (A.A.) groups

\begin{tabular}{|c|c|c|c|c|c|c|}
\hline$x^{2}$ & Group & $\begin{array}{c}\text {-ve control } \\
\text { group } \\
\mathbf{N}=10\end{array}$ & $\begin{array}{c}\text { +ve control } \\
\text { group } \\
\mathbf{N}=\mathbf{1 0}\end{array}$ & $\begin{array}{c}\text { Ascorbic } \\
\text { acid group } \\
\mathbf{N}=10\end{array}$ & \multirow[t]{2}{*}{$\mathbf{F}$} & \multirow[t]{2}{*}{$\mathbf{P}$} \\
\hline \multicolumn{2}{|l|}{ Parameter } & \multicolumn{3}{|c|}{ Mean \pm SD } & & \\
\hline \multirow{2}{*}{$\begin{array}{l}\text { Biochemical } \\
\text { parameter }\end{array}$} & GSH(mmol/dl) & $10.88 \pm 0.69$ & $10.83 \pm 0.72$ & $11.01 \pm 0.75$ & 0.166 & $\begin{array}{c}0.848 \\
\text { NS }\end{array}$ \\
\hline & $\mathrm{NO}(\mu \mathrm{mol} / \mathrm{l})$ & $42.43 \pm 5.44$ & $43.75 \pm 6.11$ & $44.26 \pm 6.75$ & 0.238 & $\begin{array}{c}0.790 \\
\text { NS }\end{array}$ \\
\hline \multirow{3}{*}{$\begin{array}{c}\text { Comet } \\
\text { test }\end{array}$} & Tail length $(\mu \mathrm{m})$ & $1.68 \pm 0.26$ & $1.65 \pm 0.25$ & $1.69 \pm 0.27$ & 0.064 & $\begin{array}{c}0.938 \\
\text { NS }\end{array}$ \\
\hline & Tail DNA\% & 26 & 26 & 1.61 & 0.404 & $\begin{array}{c}0.235 \\
\text { NS }\end{array}$ \\
\hline & $\begin{array}{l}\text { Unit tail } \\
\text { moment }\end{array}$ & $15.47 \pm 1.5$ & $15.12 \pm 1.5$ & $15.55 \pm 1.6$ & 0.222 & $\begin{array}{c}0.802 \\
\text { NS }\end{array}$ \\
\hline
\end{tabular}

N= number of rats SD: Standard Deviation GSH:reduced glutathione $\mathrm{mmol} / \mathrm{dl}$ : millimoles per deciliter. NO: Nitric oxide $\mu \mathrm{mol} / \mathrm{l}$ : micromole per liter $\mu \mathrm{m}=$ micrometers $* \mathrm{P}$ : Analysis of variance test (ANOVA) NS: nonsignificant

Significant differences among -ve control, ZnONPs and ZnONPs+AA groups regarding mean values of GSH $\&$ NO were detected by ANOVA test $(\mathrm{P}<0.001)($ Table 2).Least significant difference test (LSD) showed significant decrease in the mean values of GSH in ZnONPs when compared with -ve control and ZnONPs+AA groups $\left({ }^{\mathrm{a}} \mathrm{P}<0.001\right)$ while no significant difference in the mean values of GSH in $\mathrm{ZnONPs}+\mathrm{AA}$ when compared with control group $\left({ }^{\mathrm{b}} \mathrm{P}>0.05\right)$. Regarding mean values of $\mathrm{NO}$, there were significant increase in ZnONPs group when compared with -ve control and $\mathrm{ZnONPs}+\mathrm{AA}$ groups $\left({ }^{\mathrm{c}} \mathrm{P}<0.001\right)$ while no significant difference in the mean values of GSH in ZnONPs+AA when compared with control $\operatorname{group}\left({ }^{\mathrm{d}}\right.$ $\mathrm{P}>0.05)($ Table 2). 
Table (2): Statistical Comparison of mean values of biochemical parameters (serum reduced glutathione $(\mathrm{mmol} / \mathrm{dl})$, nitric oxide $(\mu \mathrm{mol} / \mathrm{l})$ and Comet test analysis(comet tail length $(\mu \mathrm{m})$, Tail DNA\%, Unit tail moment) in different studied groups.

\begin{tabular}{|c|c|c|c|c|c|c|}
\hline \multicolumn{2}{|c|}{$\begin{array}{c}\text { Group } \\
\text { Parameter }\end{array}$} & $\begin{array}{l}\text {-ve Control } \\
\text { (N=10) }\end{array}$ & $\begin{array}{l}\text { Zinc Oxide NPs } \\
\quad(\mathbf{N}=\mathbf{1 0})\end{array}$ & $\begin{array}{c}\text { Zinc Oxide NPs } \\
+ \text { Ascorbic acid } \\
(\mathrm{N}=10)\end{array}$ & $\mathbf{F}$ & \multirow{2}{*}{$\mathbf{p}$} \\
\hline & & \multicolumn{4}{|c|}{ Mean \pm SD } & \\
\hline \multirow{2}{*}{$\begin{array}{c}\text { Biochemical } \\
\text { parameters }\end{array}$} & $\begin{array}{c}\text { GSH: } \\
(\mathrm{mmol} / \mathrm{dl})\end{array}$ & $10.88 \pm 1.69$ & $1.46 \pm 0.64^{\mathrm{a}}$ & $8.2 \pm 1.02^{\mathrm{b}}$ & 164.1235 & $<0.001 *$ \\
\hline & $\mathrm{NO}:(\mu \mathrm{mol} / \mathrm{l})$ & $42.43 \pm 5.44$ & $114.26 \pm 12.44^{\mathrm{c}}$ & $41.02 \pm 8.12^{\mathrm{d}}$ & 210.2758 & $<0.001 *$ \\
\hline \multirow{3}{*}{ Comet test } & $\begin{array}{l}\text { Comet tail } \\
\text { length }(\mu \mathrm{m})\end{array}$ & $1.68 \pm 0.26$ & $4.07 \pm 0.10$ & $3.74 \pm 0.07$ & 609.9758 & $<0.001 *$ \\
\hline & Tail DNA\% & $1.57 \pm 0.25$ & $3.80 \pm 0.13$ & $3.48 \pm 0.04$ & 538.4815 & $<0.001 *$ \\
\hline & $\begin{array}{l}\text { Unit tail } \\
\text { moment }\end{array}$ & $2.68 \pm 0.12^{\mathrm{e}}$ & $15.47 \pm 1.3$ & $12.99 \pm 1.4^{\mathrm{f}}$ & 378.0827 & $<0.001^{*}$ \\
\hline
\end{tabular}

NPs:nanoparticles N= number of rats SD: Standard Deviation -ve:negative ZNoNPs: zincoxide nanoparticles AA: ascorbic acid GSH:reduced glutathione $\mathbf{m m o l} / \mathrm{dl}$ :

millimoles per deciliter. NO: Nitric oxide $\mu \mathrm{mol} / \mathrm{l}$ : micromole per liter $\mu \mathrm{m}=$ micrometers *P: Analysis of variance test(ANOVA). Least significant difference (Lsd); ${ }^{\mathrm{a}} \mathbf{P}<0.001 \mathrm{vs}$ ve control \& $\mathrm{ZnoNP}+\mathrm{AA}$ groups, ${ }^{\mathrm{b}} \mathrm{P}>\mathbf{0 . 0 5}$ vs control group. ${ }^{\mathrm{C}} \mathrm{P}<0.001$ vs - ve control\& ZnoNP+AA groups, ${ }^{d} \mathbf{P}>0.05$ vs - ve control group, ${ }^{\mathrm{e}} \mathbf{P}<0.001 \mathrm{vs} \mathrm{ZnoNPs}$ and ZnoNP+AA, ${ }^{\mathrm{f}} \mathbf{P}>0.05$ vs ZnONPs group

\section{Single cell gel electrophoresis} (Comet assay):

No significant differences regarding mean values of comet tail length, percentage of tail DNA (tail DNA\%) and tail moment among ve,.+ve controls and Ascorbic acid groups ( $>>0.05)$ by ANOVA test, so we used negative control group as a standard reference for comparison with other treated groups(Table1). Table (2) showed significant difference among ve control, $\mathrm{ZnONPs}$ and $\mathrm{ZnONPs}+\mathrm{AA}$ regarding comet tail length $(\mu \mathrm{m})$, tail DNA\% and unit tail moment $(\mathrm{P}<0.001)$ by ANOVA test.Least significant test revealed significant increase in unit tail moment in both ZnONPs and $\mathrm{ZnONPs}+\mathrm{AA}$ groups when compared with control group $\left({ }^{\mathrm{e}} \mathrm{p}<0.001\right)$ while no significant difference in $\mathrm{ZnONPs}+\mathrm{AA}$ when compared with ZnONPs was detected $\left({ }^{f} \mathrm{P}>0.05\right)$. Figure a showed normal lung nuclei and undamaged cells in control group (fig1,2a) while abnormal tailed nuclei \& damaged cells in ZnONPs group(fig3,4 a) and ZnONPs+AAgroups(fig 5,6a)were detected. 

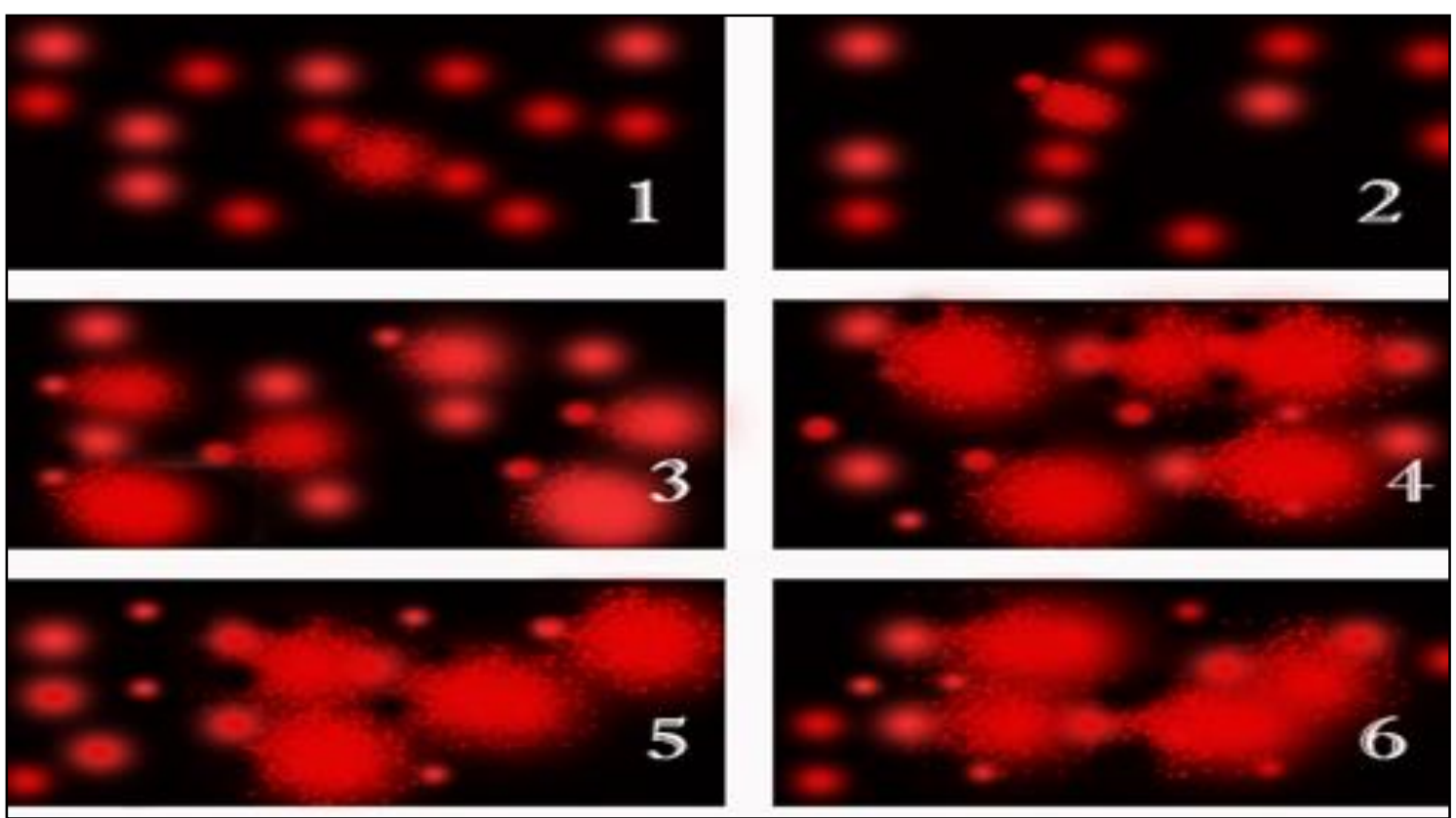

Figure (a): Nuclei of lung cells of male rats showing almost normal condensed type nuclei \& undamaged cells in control group $(\mathbf{1 , 2})$. Abnormal tailed nuclei \& damaged cells of ZnONPs treated group (3,4), abnormal tailed nuclei \& damaged cells in $\mathrm{ZnONPs+AA}$ group (5,6)

3. Histopathological results: The light microscopical examination of hematoxylin and eosin $(\mathrm{H} \& \mathrm{E})$ stained sections from the lung of control and ascorbic acid groups, showed normal spongy histological appearance with numerous alveoli connected together with alveolar pores and opens into alveolar sacs, thin inter alveolar septa, bronchioles and blood vessels (Fig. $\mathrm{b}, \mathrm{c}$ ). while diffuse alveolar damage with marked consolidation of lung tissue, collapsed alveoli, marked thickening of interalveolar septa and extravasation of
RBCs in the alveolar lumen, hyperemic foci, thickened wall pulmonary blood vessels, heavy infiltration with chronic inflammatory cells mainly lymphocytes and partial shedding of mucosal lining of bronchioles were detected in ZnONPs intoxicated group (Fig.d,e,f). In ZnONPs+ ascorbic acid treated group lung sections showed normal alveoli with some collapsed alveoli scattered inbetween, mild thickening of interalveolar septa and inflammatory cellular infiltration (Fig. g) 


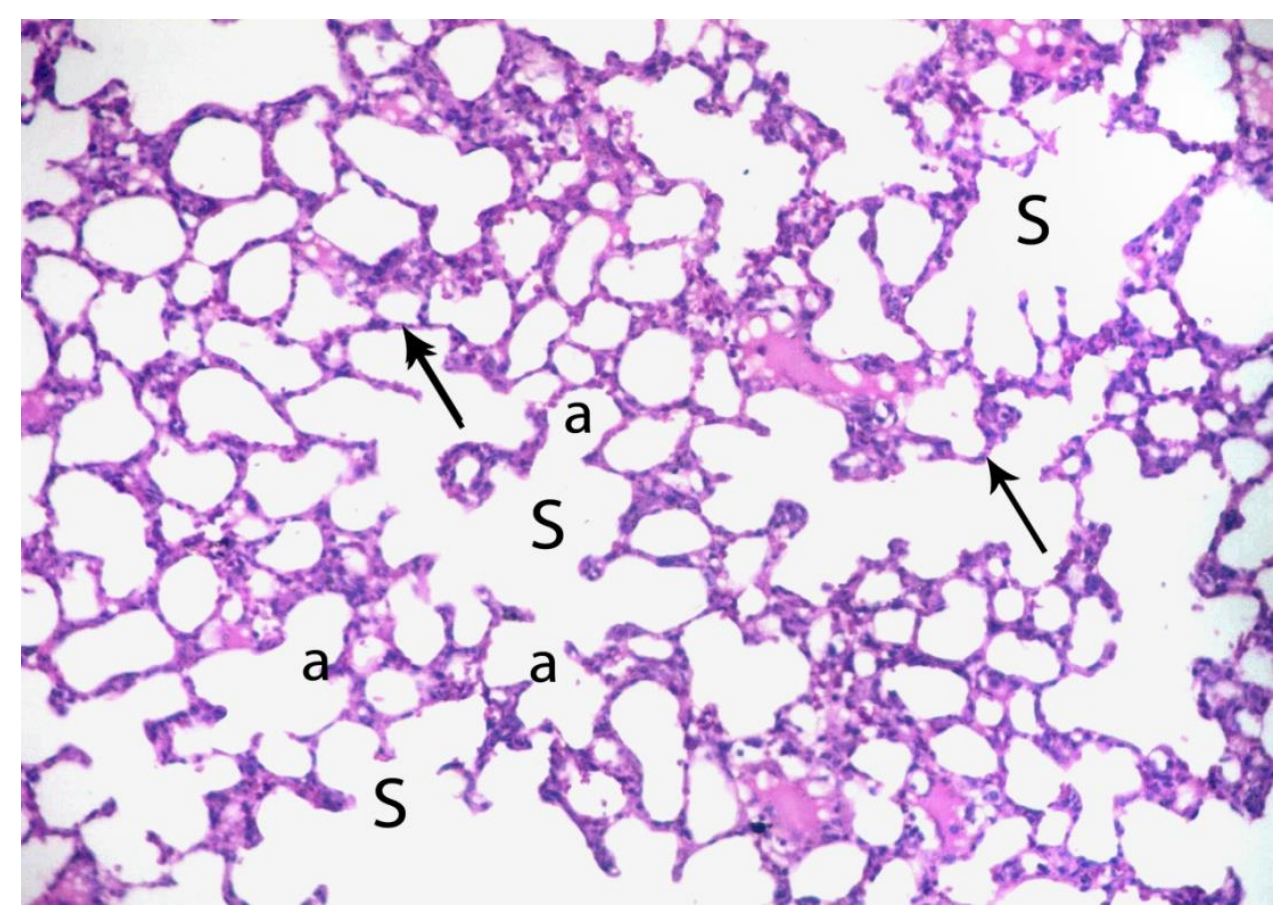

Figure (b): A photomicrograph of section in lung tissue obtained from an adult male albino rat of control group showing: Normal spongy histological appearance with numerous alveoli (a) connected together with alveolar pores and opens into alveolar sacs(s), thin inter alveolar Septa (arrow). (H\&E × 200)

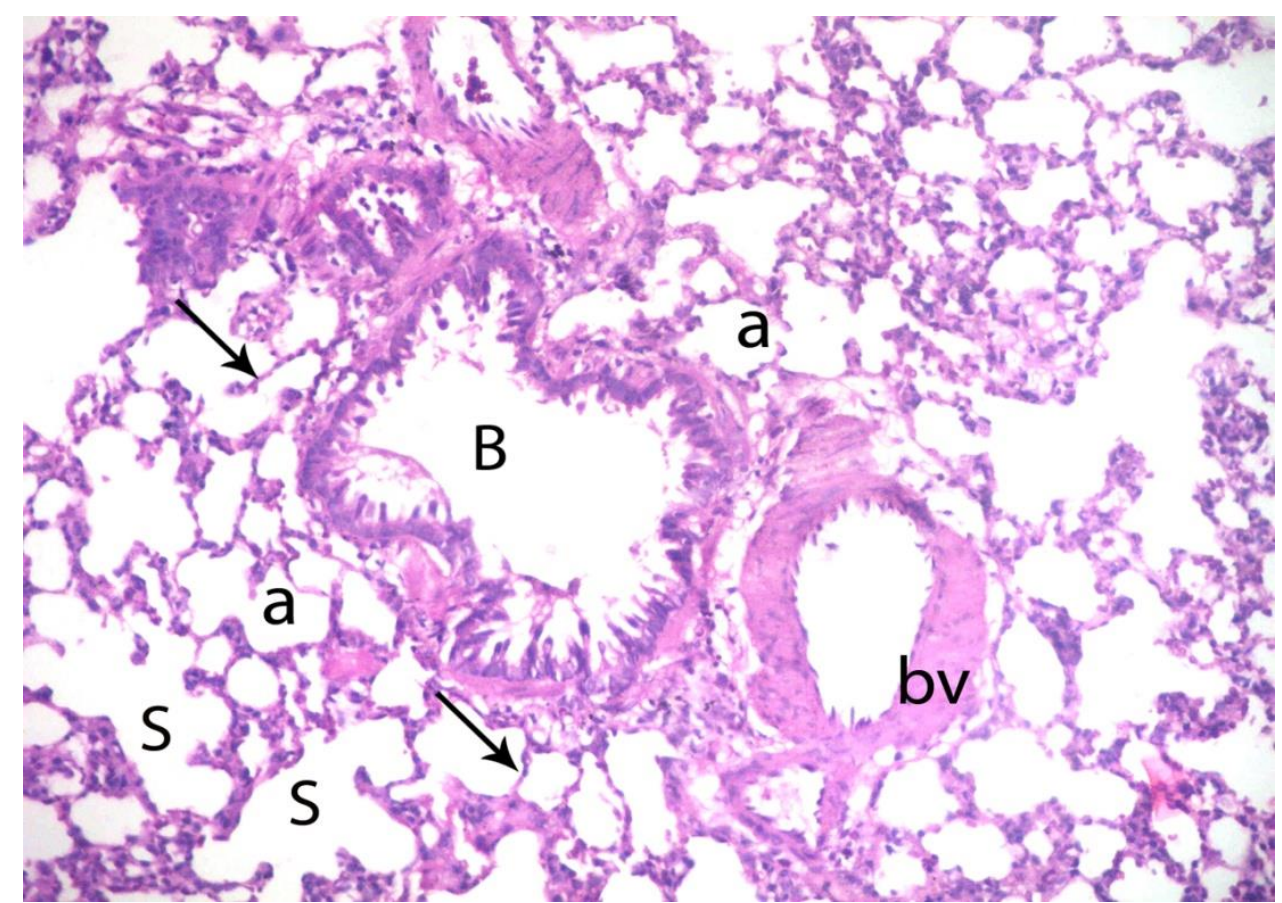

Figure (c): A photomicrograph of section of lung tissue obtained from an adult male albino rat of ascorbic acid group showing: pulmonary alveoli (a) opens into alveolar sacs(s) and thin interalveolar septa (arrow), bronchiole (B) and blood vessel (bv) $(\mathbf{H} \& \mathbf{E} \times \mathbf{2 0 0})$. 


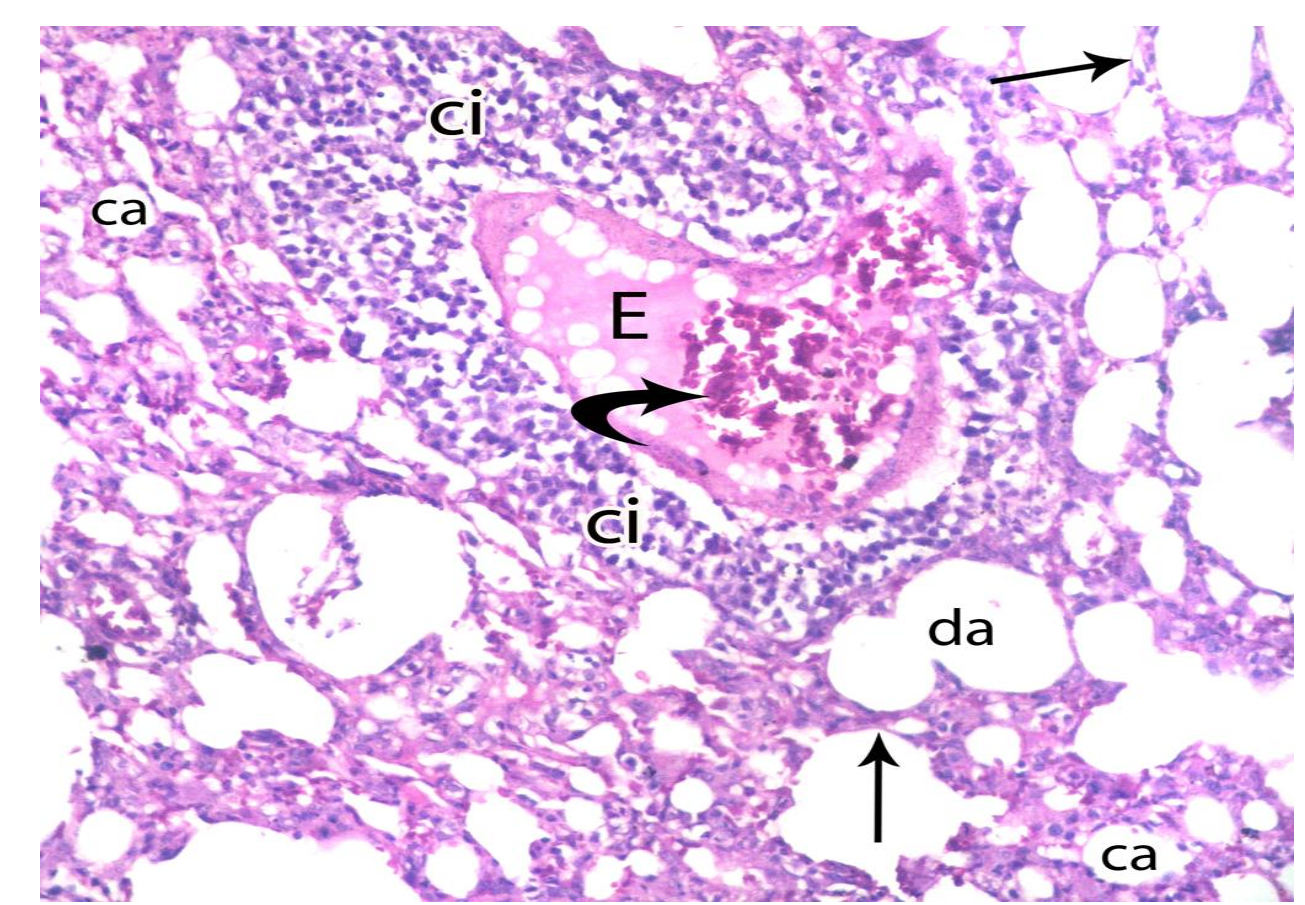

Figure(d) section in lung tissue obtained from an adult male albino rat of ZNONPs treated group showing: collapsed alveoli(ca), thick interalveolar septa (arrow), destruction of interalveolar septa with alveolar dilatation(da), heavy infiltration of inflammatory cells mainly lymphocytes(ci) with acidophilic exudates (E) and extravasation of RBCs in the alveolar lumen(curved arrow) $(\mathbf{H} \& \mathbf{E} \times \mathbf{2 0 0})$.

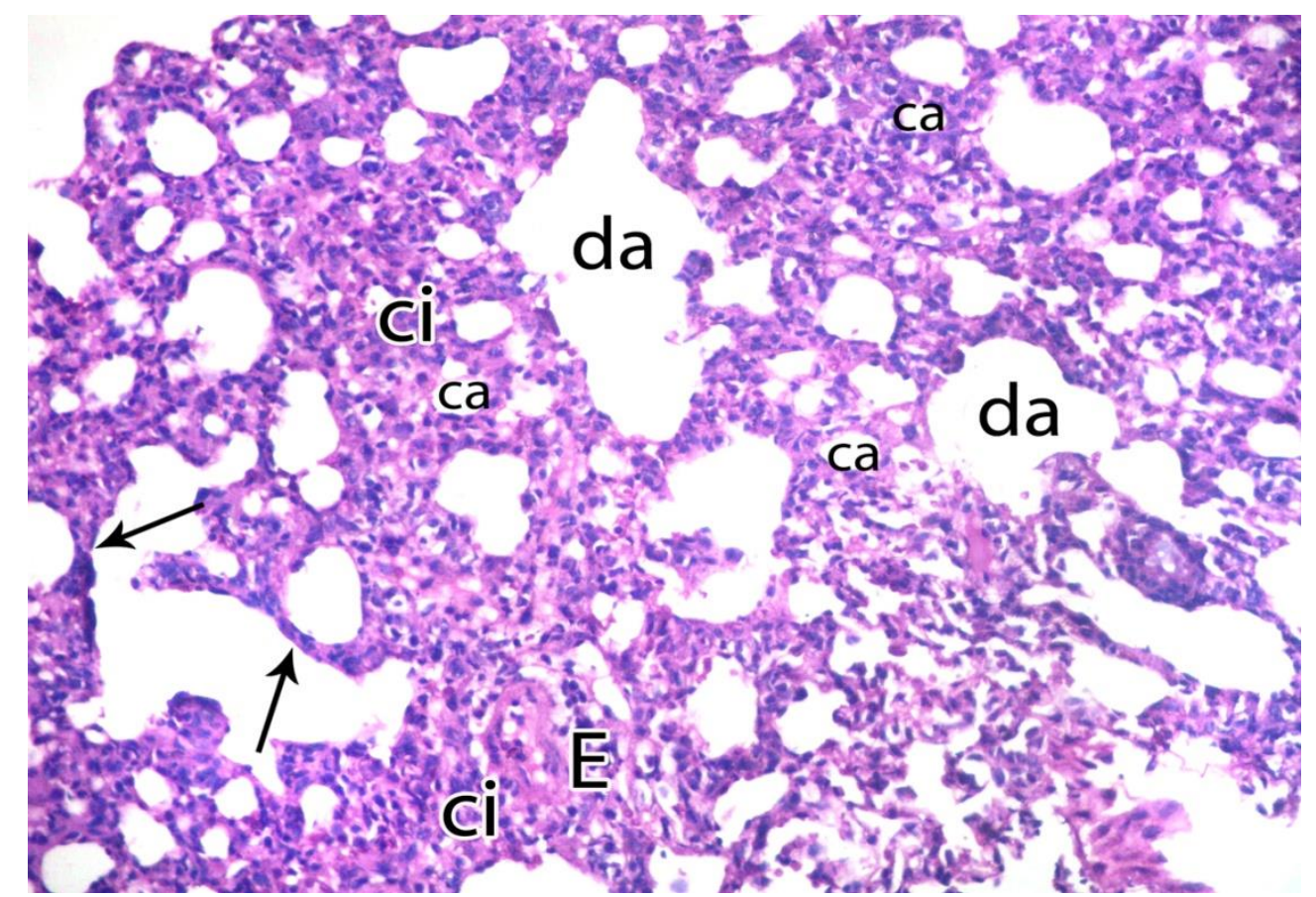

Figure(e) section in lung tissue obtained from an adult male albino rat of ZnONPs treated group showing: Thick interalveolar septa(arrow), diffuse alveolar damage, marked consolidation of lung tissue with collapsed alveoli(ca) and dilatation of adjecant ones(da) with destruction of interalveolar septa and heavy infiltration with chronic inflammatory cells(ci)and inflammatory exudates $(\mathrm{E})(\mathbf{H} \& \mathbf{E} \times \mathbf{2 0 0})$. 


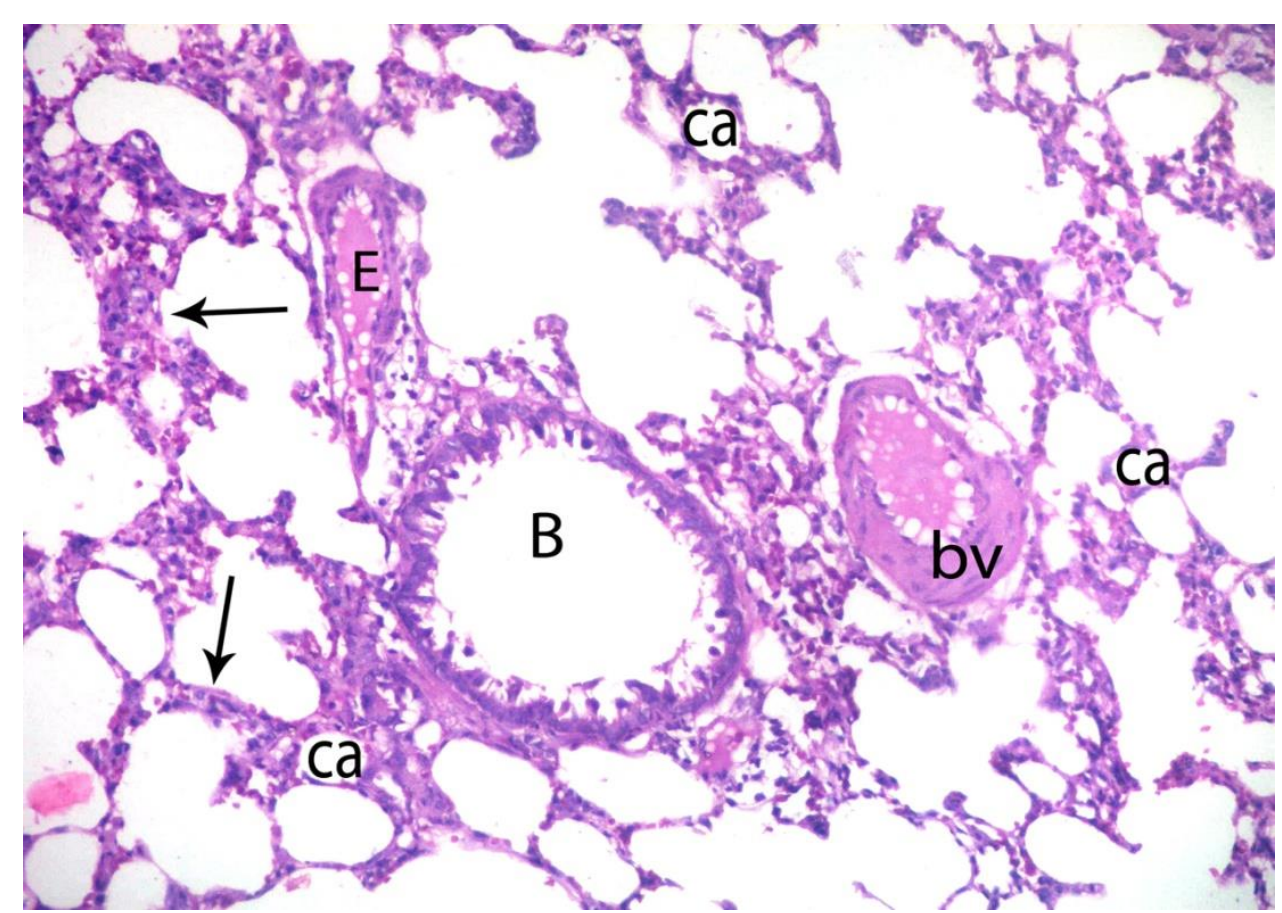

Figure (f): A photomicrograph of section in lung tissue obtained from an adult male albino rat of ZNONPs treated group showing: collapsed alveoli (ca), thickened inter alveolar septa (arrow), bronchiole (B) and thickwall and congested pulmonary blood vessels (bv)and inflammatory exudate (E) $(\mathbf{H} \& \mathbf{E} \times \mathbf{2 0 0})$.

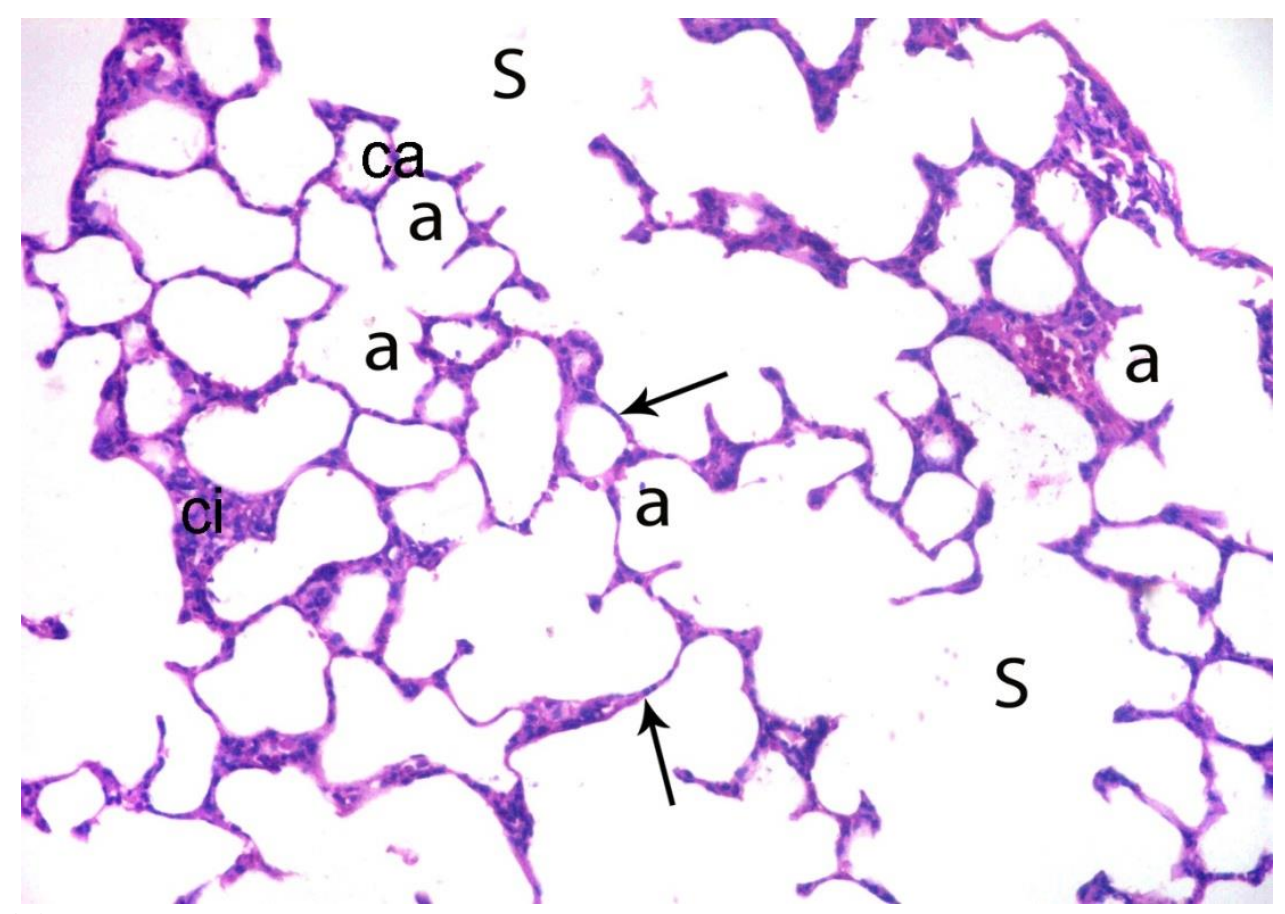

Figure (g): A photomicrograph of section of lung tissue obtained from an adult male albino rat of ZNONPs + AA group showing: Normal alveoli (a) connected together with alveolar pores and opens into alveolar sacs(s). Some collapsed alveoli in between (ca), mild thickening of interalveolar septa (arrow) and inflammatory cellular infiltration (ci) $(\mathbf{H} \& \mathbf{E} \times \mathbf{2 0 0})$. 


\section{DISCUSSION}

Zinc oxide nanoparticles are one of the most utilized nanoparticles. The human body may be intentionally or unintentionally exposed to nanoparticles through oral ingestion, inhalation, dermal exposure and intravenous injection (Jacobsen et al., 2015 and Nemenqani, 2015). Landsiedel et al. (2014) reported that nanoparticles are more toxic than larger counter parts as the dissolution rate increase with decrease particle size. So the dissolution of $\mathrm{Zn}+^{2}$ ions from the particles is the major determinant for $\mathrm{ZnO}$ mediated toxicity and cell death in mice. Earlier study suggested that uptake of dissolved zinc ions and production of reactive oxygen species is the cause for ZnoNPs cell wall damage, enhanced membrane permeability, mitochondrial weakness, DNA damage, inflammatory response, cell growth inhibition and cell death (Sirelkhatem et al., 2015).

$\mathrm{L}$-ascorbic acid is the most active form of vitamin C. being antioxidant; it acts as free radical scavenger. It can reduce DNA damage and inflammatory response of many toxic substances (Bakhshiani and Fazilati, 2014).

The aim of this study was to investigate the toxic effects of 30 days administration of ZnONPs and evaluate the ameliorative role of ascorbic acid in adult male albino rats. For this purpose, the level of serum reduced glutathione (GSH) and serum nitric oxide (No) were measured to evaluate oxidative stress caused by ZnONPs. Histopathological changes in the lung were also evaluated to confirm ZnONPs toxicity. Comet assay was done to study the presence of DNA damage

Administration of $400 \mathrm{mg} / \mathrm{kg} / \mathrm{day}$ of
ZnoNPs for 30 days showed significant decrease in serum GSH as a marker of oxidative stress. This observations were in line with the results of DeBerardis et al. (2010), who reported that in vitro studies on human colon carcinoma cell line exposed to 50-70 $\mathrm{nm} \mathrm{ZnONPs}$ resulted in decreased viability, increased hydrogen peroxide free radicles and decreased glutathione (GSH) levels. This decrease in GSH levels can be due to either direct action of ZnONPs on GSH synthesis Khan et al. (2015) or interference with its action in scavenging free radicals (Ansari et al., 2010).

However, in contrast to this, Afifi et al. (2015) demonstrated that ZnONPs $(10 \mathrm{mg} / \mathrm{kg})$ has the ability to protect the tissue from oxidative stress induced by diabetes in rats proved by elevation of the decreased levels of GSH. Moreover, Dkhil et al. (2015) reported that ZnONPs in a dose $10 \mathrm{mg} / \mathrm{kg}$ for 5 days are able to prevent the loss of GSH during oxidative damage induced by infection with Eimeria Papillata in jejunum of mice. However, this contrast could be explained by their usage of low dose $(10 \mathrm{mg} / \mathrm{kg})$ and short period of experiment (5 days).

A significant increase in mean values of serum GSH in ZnONPs +Ascorbic acid group when compared with $\mathrm{ZnONPs}$ intoxicated group was detected. These results can be supported by, Nemanqani et al. (2015) who recorded that oral administration of vitamin c $(30 \mathrm{mg} / \mathrm{kg})$ along with zinc oxide nano particles resulted in restoration of hepatic GSH levels in male wister rats exposed to300mg and $1 \mathrm{~g} / \mathrm{kg} /$ day for four weeks.

Also, Fukui et al. (2015) illustrated that oral intake of ascorbic 
acid can attenuate acute pulmonary oxidative stress and inflammation caused by intra tracheal injection of ZnONPs. Moreover, Othman and Hussein, (2015) mentioned that while GSH normally functions to maintain vitamin $\mathrm{C}$ and other cellular components in the reduced states, vitamin $\mathrm{C}$ can serve as an essential antioxidant in the presence of severe GSH deficiency.

Ascorbic acid is the most abundant hydrophilic antioxidant in the body acts in combating free radicles and protecting bio membranes from oxidative damage induced by pollution (Hassan and Jassim, 2010 and Skŕivan et al., 2012).

From the previous studies it is clear that ascorbic acid can restore the decreased levels of GSH induced by ZnONPs through suppression of oxidative stress and lipid peroxidation together with neutralization of the excess amounts of free radicals keeping GSH in the reduced state.

The results of present study showed highly significant increase in mean values of serum NO $(p<0.001)$ in $\mathrm{ZnONPs}$ group when compared with negative control group.

The results of the present study were in accordance with Fahmy et al. (2014) who revealed that there was significant increase in NO levels after exposure to $\mathrm{ZnONPs}$ ( 7 and $35 \mu \mathrm{g} / \mathrm{ml}$ ) in hemolymph and tissues of fresh water snails Biomphalaria Alexandrina compared with their corresponding controls after 3 weeks.

High amounts of $\mathrm{NO}$ are released from the inducible nitric oxide synthase (iNOS) enzyme isoform in response to inflammatory stimuli from variety of cell types (Pfeilschifter et al., 1992 and Saura et al., 1995). Increased serum nitric oxide levels in ZnONPs intoxicated rats suggest that these nanoparticles can induce oxidative stress and increase pro inflammatory mediators (Faddah et al., 2012).

Oxidative stress and the rising levels of free radicals have a strong relation with the increased levels of inducible nitric oxide synthase (iNOS) protein in the lung with production of NO as a compensatory mechanism (Porter et al., 2006).

In contrast to our results, Dawei et al. (2009) reported that ZnONPs (0.4, 1.6 and $6.4 \mu \mathrm{g} / \mathrm{ml}$ ) are able to protect cell membrane integrity in mice intestinal epithelial cells against oxidative stress damage, increase antioxidant enzyme levels and decrease nitric oxide (NO) and malondialdehyde (MDA) levels.

Furthermore, Hussein et al. (2014) concluded that $\mathrm{ZnONPs}(10 \mathrm{mg} / \mathrm{kg} /$ day) administration for one month significantly reduces the elevated levels of $\mathrm{NO}$ in the serum of diabetic rats.

The results of the present study showed no-significant difference in mean values of serum NO in ZnONPs + AA group when compared with -ve control group, but there was highly significant decrease in mean values of serum NO in ZnONPs + AA group when compared with ZnONPs intoxicated group.

These results coincide with Fukui et al. (2015) who reported that AA has a preventive effect against lung inflammation caused by ZnONPs. This was attributed to inhibition of the production of reactive oxygen species (ROS) caused by activation of phagocytes, such as neutrophils and macrophages and suppression of cytokine-induced neutrophil chemoattractant (CINC) genes. 
Improvement of oxidative stress was associated with decreased levels of proinflammatory mediators such as NO.

In addition, Baltalarli et al. (2006) reported that administration of moderate doses of vitamin $\mathrm{C}$ almost completely prevents protein damage, apoptosis and lung injury caused by several toxic materials (

However, in contrast to our results, Wang et al. (2014) suggested that vitamin $\mathrm{C}$ increase the cytotoxicity of ZnONPs. These results could be attributed to that the acidity of ascorbic acid enhances the release of $\mathrm{Zn}$ ions from $\mathrm{ZnONPs}$ to an aqueous medium and inducing more serious cytotoxicity by increased levels of zinc ions.

Also, Abo Zeid et al. (2015) demonstrated that nanocomposite compound (nanocurcumin+ surfactant+ ZnONPs+ vitamin C) causes no significant decrease in NO levels which were elevated in experimentally tumor bearing female mice due to cancer after 2 and 4 weeks.

In the present study, light microscope examination of sections of the lung of Zinc Oxide Nanoparticles intoxicated group showed collapsed alveoli, destruction of interalveolar septa with alveolar dilatation, thick interalveolar septa, and heavy infiltration of inflammatory cells, inflammatory exudate and extravasation of RBCs in the interstitium.

The results of the present study coincided with those of Song et al. (2010), Shokouhian et al. (2013) \& Valdiglesias et al. (2013) who investigated the toxic effects of ZnONPs in rats by oral administration resulting in enhancement of phagocytosis by macrophages causing lymphocytic

perivasculitis, pribronchiolitis and interstitial pneumonia, interstitial fibrosis, contraction and atelectasis of parenchymal lung tissue, patterns of chronic necrotic bronchiolitis and excretion of exudates in rat lung. It is also documented that $\mathrm{ZnO}$ nanoparticles could elevate the level of lactate dehydrogenase (LDH) and induce inflammation and apoptosis. Also, Thickening of alveolar septal wall thickening, vascular congestion, inflammatory infiltration and focal loss of epithelial integrity was reported following exposed to small doses $(1 \mathrm{mg} / \mathrm{m} 3)$ of ZnONPs by inhalation for short period ( 5 days) Wesselkamper et al. (2001)

Moreover, Jacobsen et al. (2015) reported that exposure of mice to zinc oxide nanoparticles $(0.3 \mathrm{mg} / \mathrm{kg})$ cause strong pulmonary toxicity with cell death, epithelial damage, desquamation and injury to the alveolar barrier allowing fluids to enter the pulmonary space.

Yousef and El-Rajhi, (2013) attributed lung injury caused by $\mathrm{ZnONPs}$ to oxidative stress and free radical damage.

Also, Zidan, (2011) explained thickening of interalveolar septa induced by ZnONPs by the increased interstitial collagen fiber deposition and marked cellular infiltration with lymphocytes, neutrophils, eosinophils and macrophages. Moreover, vascular congestion and cellular infiltration of the lung tissue could be caused by changes of the vascular integrity of the lung vessels causing disruption of the endothelial barrier and increased capillary permeability.

Furthermore, Nel et al. (2009) demonstrated that uptake of ZnONPs in 
acidic lining of lung cells accelerates dissolution of these particles leading to lysosomal damage, mitochondrial disturbance, production of ROS and cytokines.

Those results are in consistence with the findings of the study as GSH; biomarker of oxidative stress was decreased significantly in ZnONPs treated rats. Also, NO; an inflammatory mediator was increased significantly as a compensatory mechanism occurs with pulmonary inflammation and oxidative damage.

The light microscope examination of sections of the lung of $\mathrm{ZnONPs}+\mathrm{AA}$ group revealed partial improvement in histopathological changes. These results are in agreement with, Nemenqani, (2015) who reported that rats treated with Vit $\mathrm{c}$ along with ZnONPs show well preserved lung tissue with partial improvement in lung histo pathology. Also, vitamin C administration $\quad(30 \mathrm{mg} / \mathrm{kg}) \quad$ with ZnONPs was found to decrease congestion and inflammatory infiltration in the tissues. Nemanqani et al. (2015)

Moreover, Fukui et al. (2015) mentioned that AA is a radicalscavenging antioxidant has the ability to inhibit the induction of pulmonary oxidative stress, injury and inflammation observed in the rat lung 1 day after intratracheal instillation of ZnONPs.

The comet assay is a widely used assay in ultimate research for DNA damage and repair, genotoxicity testing of novel chemicals and pharmaceuticals and environmental bio monitoring. However, comet assay has been working for toxicity assessment of highly reactive nanoparticles; and several studies had used it to investigate the potential toxicity of manufactured nanoparticles by assessing DNA strand breaks or oxidative DNA lesions (Karlsson, 2010 \& Karlsson et al., 2015).

In this study the effect of ZnONPs was demonstrated at molecular level by Comet assay to investigate the ability of ZnONPs to generate DNA damage and cause long term side effects in offsprings. Our results showed that administration of ZnONPs at dose $400 \mathrm{mg} / \mathrm{kg} /$ day for 4 weeks causes DNA strand breaks and disrepair of damaged DNA strands evidenced by increase in unit tail moment.

These results are in accordance with Sharma et al. (2009); Yang et al. (2009); Osman et al. (2010); Sharma et al. (2011) ; Guan et al. (2012) and Dubey et al. (2015) who reported that different concentrations of ZnONPs are cytotoxic and genotoxic to different organs and cell lines in different organisms. This genotoxic effect reported to be dose dependent Muserrat et al. (2009) and even after short term exposure Gerloff et al. (2009).

These results could be explained by Singh et al. (2009) \& Yang et al. (2009) who stated that increased ROS induced by nanoparticles in lysosomes can cause DNA point mutations or induce single-or double-strand breaks. Due to their small size; nanoparticles accumulate around the nucleus and few of them may diffuse through nuclear pores from where protein transport take place and this augment DNA damage caused by ROS (Simko et al., 2011).

Also, Hausladen and Stamler (1999) \& Murphy, (1999) concluded that unregulated production of NO can lead to damage of cellular proteins, DNA damage, cell injury and death and 
this may be a cause of DNA damage induced by $\mathrm{ZnONPs}$.

In addition, the presence of free zinc ions may be the cause of ROSdriven cytotoxicity and genotoxicity (Song et al., 2010).

However, other studies noted weak or no genotoxic effect for ZnONPs when internalized into bacteria Kumar et al. (2011) \& Nam et al. (2012).But Pan et al. (2010)stated earlier that attributed weak mutagenic effect of ZnONPs in bacteria to reduced particle size (bare ZnONPs $<100 \mathrm{~nm}$ ), low dose response and low uptake of NPs.

The results of this work showed no-significant difference in mean values of unit tail moment in ZnONPs + AA group when compared with ZnONPs intoxicated group, but there was highly significant increase when compared with negative control group.

These results are in agreement with the findings of Bhat et al. (2006) who reported that several in vitro experiments with cell lines indicate that vitamin $\mathrm{C}$ in the presence of transition metal ions acts as a prooxidant and increases the amount of damage to genetic material in human lymphocytes.

In addition, Wang et al. (2014) mentioned that co-incubation of gastric epithelial cell lines and neural stem cells with ZnONPs and vitamin $\mathrm{C}$ lead to significant increase in the average fluorescence intensity in cells measured by DNA fluorescent staining indicating nuclear and mitochondrial damage.

These results suggest that vitamin $\mathrm{C}$ has a minimal protective effect on ZnONPs induced DNA damage and these results could be explained by low dose of vitamin $\mathrm{C}$, short duration of supplementation or the fact that increased DNA damage needs long time with sufficient doses of vitamin $\mathrm{C}$ for the tissue to restore normal genetic and chromosomal appearance (Bhat et al., 2006).

On the contrary to our results, Blasiak and Kowalik, (2001); Blasiak et al. (2004); Robichova et al. (2004) and Arranz et al. (2007) evaluated the protective effect of vit $\mathrm{C}$ against several free radicals generating chemicals ( $\mathrm{N}$ nitrosamine, acrylamide and ZnONPs) by numerous invivo and invitro studies. Vitamin $\mathrm{C}$ significantly decreased DNA damage proved by Comet analysis.

\section{CONCLUSION}

Oral administration of $1 / 20$ LD50 of $\mathrm{ZnONPs}$ led to decrease in serum GSH as an indicator of ZnONPs induced oxidative stress and increased levels of $\mathrm{NO}$ as a compensatory mechanism resulting from oxidative stress. Also, it causes DNA damage evidenced by Comet assay with histopathological changes in lung. Ascorbic acid administration along with ZnONPs led to attenuation of oxidative stress and pulmonary toxicity induced by ZnONPs, but there was non-significant improvement in DNA damage proved by Comet assay.

\section{RECOMMENDATION}

Zinc oxide nanoparticles should be used cautiously to gain the benefits of nanotechnology and avoid its possible draw backs. Public education regarding the health hazards of ZnONPs products should be adapted. Control occupational exposure to ZnONPs by continuous monitoring of work environment level and keep it within the recommended exposure limits. Increasing the awareness of workers about the proper handling of ZnoNPS materials with periodical clinical and laboratory examinations are needed. 


\section{REFERENCES}

Abo Zeid OA, Abdel maksoud H, Badwi AM, Hussein MA, Elsheikha MF. (2015): Biochemical effect of some novel nanocomposite on metabolic changes in experimentally induced tumor in female mice. Benha Vet. Med. J.; 28: 138-149.

Afifi M, Almaghrabi OM, Kadasa NM. (2015): Ameliorative Effect of Zinc Oxide Nanoparticles on Antioxidants and Sperm Characteristics in StreptozotocinInduced Diabetic Rat Testes. Biomed. Res. Int.; 12: 1-6.

Ansari RW, Shuka RK, Yadav RS, Seth K, Singh AD, Agrawal AK, Islam $F$, Khanna V,De Berardis B, Civitelli G, Condello $M$. (2010): Exposure to $\mathrm{ZnO}$ nanoparticles induces oxidative stress and cytotoxicity in human colon carcinoma cells. Toxicol. Appl. Pharmacol.; 246: 116-127.

Arranz N, Haza AI, Garcia A, Rafter $J$ and Morales P. (2007): Protective effect of vitamin C towards N-nitrosamine-induced DNA damage in the single-cell gel electrophoresis (SCGE)/HepG2 assay. Toxicol. InVitro. ; 21(7), 1311-1317.

Arrigoni O, De Tullio MC. (2002): Ascorbic acid: Much more than just an antioxidant. Biochim. Biophys. Acta - Gen. Subj.; 1569:1-9.

Bakhshiani S, Fazilati M. (2014): Vitamin $\mathrm{C}$ can reduce toxic effects of Nano Zinc Oxide. Int. Res. J. Biol. Sci. ; 3:65-70.

Baltalarli A, Ozcan V, Ferda B, Aybek H, Sacar M, Onem G, Goksin I, Demir S, Dunn I, Ellegala D, Kim D, Litvack Z.
(2006): Ascorbic acid (vitamin C) and ilopros attenuate the lung injury caused by ischemia/reperfusion of the lower extremities of rats. Ann. Vasc. Surgery; 20: 49-55.

Bancroft JD, Gamble M. (2002): Theory and practice of histological techniques, fifth ed.Churchill Livingstone Pub., Edinburg and London.

Bhat SH, Azmi AS, Hanif S, Hadi SM. (2006): Ascorbic acid mobilizes endogenous copper in human peripheral lymphocytes leading to oxidative DNA breakage: A putative mechanism for anticancer properties. Int. J. Biochem. Cell Biol.; 38, 20742081.

Błasiak J, Kowalik J. (2001): Protective action of vitamin C against DNA damage induced by selenium-cisplatin conjugate. Acta Biochim. Pol.;48: 233-240.

Blasiak J, Gloc E, Wozniak K, Czechowska A. (2004): Genotoxicity of acrylamide in human lymphocytes. Chem. Biol. Interact.; 149:137-149.

Dawei AI, Zhisheng W, Angu $Z$. (2009): Protective Effects of Nano$\mathrm{ZnO}$ on the Primary Culture Mice Intestinal Epithelial Cells in-vitro Against Oxidative Injury. Int. J. Nanotechnol. App.;3: 1-6.

De Berardis B, Civitelli G, Condello M, Lista P, Pozzi R, Arancia G, Meschini S. (2010): Exposure to $\mathrm{ZnO}$ nanoparticles induces oxidative stress and cytotoxicity in human colon carcinoma cells. Toxicol. Appl. Pharmacol.; 246:116-127.

Devi KR, Latha CK. (2011): Protective role of vitamin $\mathrm{c}$ against 
cytotoxicity induced by adriamycin in mice. Int. J. Pharm. Life Sci.; 2: 1195-1202.

Dkhil AM, Al-Quraishy S, Rizwan W. (2015): Anticoccidial and antioxidant activities of zinc oxide nanoparticles on Eimeria papillatainduced infection in the jejunum. Int. J. Nanomedicine.; 10: 19611968.

Dubey A, Goswami M, Yadav K, Chaudhary D. (2015): Oxidative Stress and Nano-Toxicity Induced by $\mathrm{TiO} 2$ and $\mathrm{ZnO}$ on WAG Cell Line. PLoS One; 10:1-26

Elsammad NM, Abd Elhaleem AH, Hassan Sh, Elshaer M, Badawi AM. (2014): Evaluation of The Protective Effect of Zinc Oxide / Ascorbyl Palmitate NanoComposite on Cadmium- Induced Hepatotoxicity and Nephrotoxicity in Rats. Int. J. Pharm. Sci. Rev. Res.; 29: 232-239.

Faddah LM, Baky N, Al-Rasheed NM, Fatani AJ, Atteya M. (2012): Role of quercetin and arginine in ameliorating nano zinc oxide-induced nephrotoxicity in rats. BMC Complement. Altern. Med.; 12: 60.

Fahmy SR, Abdel-Ghaffar F, Bakry FA, Sayed DA. (2014): Ecotoxicological effect of sublethal exposure to zinc oxide nanoparticles on freshwater snail Biomphalaria alexandrina. Arch. Environ. Contam. Toxicol.; 67: 192-202.

Fukui H, Iwahashi H, Endoh S, Nishio K, Yoshida Y, Hagihara Y, Horie M. (2015): Ascorbic acid attenuates acute pulmonary oxidative stress and inflammation caused by zinc oxide nanoparticles. J. Occup. Health; 57:118-125.
George S, Pokhrel S, Xia T, Gilbert B, Ji Z, Schowalter M, Rosenauer A, Damoiseaux $\mathbf{R}$, Bradley KA, Mädler L, Nel AE. (2010): Use of a rapid cytotoxicity screening approach to engineer a safer zinc oxide nanoparticle through iron doping. ACS Nano.; 4:15-29.

Gerloff K, Albrecht C, Boots AW, Förster I, Schins RPF. (2009): Cytotoxicity and oxidative DNA damage by nanoparticles in human intestinal Caco-2 cells. Nanotoxicology.; 3: 355-64.

Guan R, Kang T, Lu F, Zhang Z, Shen H, Liu $M$. (2012):Cytotoxicity, oxidative stress, and genotoxicity in human hepatocyte and embryonic kidney cells exposed to $\mathrm{ZnO}$ nanoparticles. Nanoscale Res. Lett.; 7: 602.

Hassan AA, Jassim HM. (2010): Effect of treating lactating rats with lead acetate and its interaction with vitamin $\mathrm{E}$ or $\mathrm{C}$ on neurobehavior development and some biochemical parameters in their pups. Iraqi J. Vet. Sci.; 24: 45-52.

Hausladen A, Stamler JS.(1999): Nitrosative stress. Methods Enzymol.; 300: 389-395.

Hussein SA, EL-Senosi YA, El-Dawy K, Baz HA. (2014): Protective effect of zinc oxide nanoparticles on oxidative stress in experimentalinduced diabetes in rats. Benha Vet. Med. J.; 27: 405-414.

Institute of Laboratory Animal resource (1996): Guide for the care and use of laboratory animals. Inst. Lab. Anim. Resour. Natl. Acad. Press 1441996 SRC, xii,: 125.

Jacobsen N, Stoeger T, Brule S, 
Saber A, Beyerle A, Vietti G, Mortensen A, Szarek J, Budtz H, Kermanizadeh A, Banerjee A, Erkal N, Vugel U, Wallin $\mathbf{H}$, Moller P. (2015): Acute and subacute pulmonary toxicity and mortality in mice after intratracheal instillation of $\mathrm{ZnO}$ nanoparticles in three laboratories. Food chem. Toxicol.; 85: 84-95.

Johnson MD. (2007): The Rats, in: Gad, S.C.(Eds), Animal Models of Toxicology, second ed. Taylor and Francis, New York.; pp.150-171.

Johnston HJ, Hutchison G, Christensen FM, Peters S, Stone HS. (2010): A review of the in vivo and in vitro toxicity of silver and gold particulates. Particle attributes and biological mechanisms responsible for the observed toxicity. Crit. Rev. Toxicol.; 40, 328-346.

Kao YY, Chiung YM, Chen YC, Cheng TJ, Liu PS. (2012): Zinc oxide nanoparticles interfere with zinc ion homeostasis to cause cytotoxicity. Toxicol. Sci.; 125: 462-472.

Karlsson HL. (2010): The comet assay in nanotoxicology research. Anal. Bioanal. Chem.; 398(2):651-66 .

Karlsson HL, Di Bucchianico S, Collins AR, Dusinska M. (2015): Can the comet assay be used reliably to detect nanoparticleinduced genotoxicity? Environ. Mol. Mutagen.; 56(2):82-96

Khan M, Naqvi A, Ahmad A. (2015): Comparative study of the cytotoxic and genotoxic potentials of Zinc oxide and Titanium dioxide nanoparticles. Toxicol. Rep.; 2: 765-774.

Kiernan J. (2002): Histological and Histochemical Methods: Theory and Practice, Construction Management \& Economics..

Kumar A, Pandey AK, Singh SS, Shenker R, Dhawan A. (2011): Cellular uptake and mutagenic potential of metal oxide nanoparticles in bacterial cells. Chemosphere.; 83: 1124-1132.

Landsiedel R, Sauer UG, Ma-Hock L, Schnekenburger J, Wiemann M. (2014): Pulmonary toxicity of nanomaterials: a critical comparison of published in vitro assays and in vivo inhalation or instillation studies. Nanomedicine (Lond).; 9: 2557-85.

Luyts K, Smulders S, Napierska D, Van Kerckhoven S, Poels $\mathrm{K}$, Scheers H, Hemmeryckx B, Nemery B, Hoylaerts MF, Hoet PHM. (2014): Pulmonary and hemostatic toxicity of multi-walled carbon nanotubes and zinc oxide nanoparticles after pulmonary exposure in Bmal1 knockout mice. Part. Fibre Toxicol.; 11: 61.

Montgomery HAC, Dymock JF. (1961): The determination of nitrite in water. Analyst.; 86: 414-416.

Moron M, Depierre J, Mannervik B. (1979): Levels of glutathione, glutathione reductase and glutathione S-transferase activities in rat lung and liver. Biochim. Biophys. Acta - Gen. Subj.; 582: 67-78.

Murphy MP. (1999): Nitric oxide and cell death. Biochim. Biophys. Acta - Bioenerg.; 1411: 401-414.

Musarrat J, Saquib Q, Azam A, Naqvi SAH. (2009): Zinc oxide nanoparticles-induced DNA damage in human lymphocytes. Int. J. Nanoparticles; 2: 402-415.

Nam SH, Kim SW, An YJ. (2012): No evidence of the genotoxic 
potential of gold, silver, zinc oxide and titanium dioxide nanoparticles in the SOS chromotest. J. Appl. Toxicol.; 3: 12-14.

Nel AE, Madler L, Velegol D, Xia T, Hoek EM, Somasundaran $P$, Klaessig F, Castranova V, Thompson M. (2009): Understanding biophysicochemical interactions at the nano-bio interface. Nat. Mater.; 8:543-557.

Nemenqani D. (2015): The Ameliorating Effect of Vitamin C against Cardiopulmonary Toxicity of Zinc Oxide Nanoparticals. Int. Res. J. Appl. Basic Sci.; 9: 1102-1109.

Nemanqani D, El Gharib O, Ahmed A, Baiuomy A. (2015): The protective effects of antioxidants (vit c) against hepatic oxidative damage induced by zinc oxide nano particles. Int. Res. J. Appl. Basic sci.; 9: 672-679.

NIOSH (National institute For Occupational Safety and Health). (2010): Zinc Oxide. The registry of toxic effects of chemical substances..Available:http://www.o sha.gov/SLTC/healthguidlines/zinc oxide/recognition.html. (Access date: July, 2015)

Osmond MJ, McCall MJ. (2010): Zinc oxide nanoparticles in modern sunscreens: an analysis of potential exposure and hazard. Nanotoxicology.;4: 15-41.

Osman IF, Baumgartner A, Cemeli E, Fletcher JN, Anderson D.(2010): Genotoxicity and cytotoxicity of zinc oxide and titanium dioxide in HEp-2 cells. Nanomedicine ; 5: 1193-203.

Othman A, Hussein M. (2015): In vitro antibacterial, antioxidant and hepatoprotective effect of curcumin-zinc oxide nanoparticles in combination. Int. J. Pharm. Bio. Sci.; 6:105-118.

Pan X, Redding JE, Wiley PA, Wen L, McConnell JS, Zhang B.(2010): Mutagenicity evaluation of metal oxide nanoparticles by the bacterial reverse mutation assay. Chemosphere; 79: 113-116.

Pfeilschifter J, Rob P, Mulsch A, Fandrey J, Vosbeck K, Busse R. (1992): Interleukin $1 \beta$ and tumour necrosis factor $\alpha$ induce a macrophage-type of nitric oxide synthase in rat renal mesangial cells. Eur. J. Biochem.; 203: 251 255

Porter DW, Millecchia LL, Willard P, Robinson VA, Ramsey D, McLaurin J, Khan A, Brumbaugh $\mathrm{K}$, Beighley CM, Teass A, Castranova V. (2006): Nitric oxide and reactive oxygen species production causes progressive damage in rats after cessation of silica inhalation. Toxicol. Sci. ; 90: 188-197.

Robichová S, Slamenová D, Chalupa I, Sebová L.(2004): DNA lesions and cytogenetic changes induced by N-nitrosomorpholine in HepG2, V79 and VH10 cells: the protective effects of vitamins $\mathrm{A}, \mathrm{C}$ and $\mathrm{E}$. Mutat. Res.; 560: 91- 99.

Saura M, López S, Rodríguez Puyol M, Rodríguez Puyol D, Lamas S.(1995): Regulation of inducible nitric oxide synthase expression in rat mesangial cells and isolated glomeruli. Kidney Int.; 47: 500-9.

Sharma V, Shukla RK, Saxena N, Parmar D, Das M, Dhawan A.(2009): DNA damaging potential of zinc oxide nanoparticles in human epidermal cells. Toxicol. Lett.; 185: 211-218. 
Sharma V, Anderson D, Dhawan A.(2011): Zinc oxide nanoparticles induce oxidative stress and genotoxicity in human liver cells (HepG2). J. Biomed. Nanotechnol.; 7: 98-99.

Shokouhian A, Sohheili S, Moradhaseli S, Fazli L, Ardestani MS, Ghorbani M. (2013): Toxicity of zinc oxide nanoparticles in lung tissue after repeated oral administration. Am. J. Pharmacol. Toxicol.; 8: 148-154.

Simko M, Fiedeler U, Gazso A, Nentwich M. (2011): The impact of nanoparticles on cellular functions. Nano Trust Dossier.;7: 151-164.

Singh NP, McCoy MT, Tice RR, Schneider EL.(1988): A simple technique for quantitation of low levels of DNA damage in individual cells. Exp Cell Res.; 175: 184-191.

Singh N, Manshian B, Jenkins GJS, Griffiths SM, Williams PM, Maffeis TGG, Wright CJ, Doak SH.(2009): Nanogenotoxicology: The DNA damaging potential of engineered nanomaterials. Biomaterials.; 30(23-24):3891-914.

Sirelkhatim A, Mahmud S, Seeni A, Kaus NHM, Ann LC, Bakhori SKM, Hasan H, Mohamad D.(2015): Review on zinc oxide nanoparticles: Antibacterial activity and toxicity mechanism. NanoMicro Lett.; 7: 219-242.

Skŕivan M, Marounek M, Englmaierová M, Skrivanová E. (2012): Influence of dietary vitamin $\mathrm{C}$ and selenium, alone and in combination, on the composition and oxidative stability of meat of broilers. Food Chem.;130: 660664.
Song W, Zhang J, Guo J, Zhang J, Ding F, Li L, Sun Z. (2010): Role of the dissolved zinc ion and reactive oxygen species in cytotoxicity of $\mathrm{ZnO}$ nanoparticles. Toxicol. Lett.; 199: 389-397.

Valdiglesias V, Costa C, Kiliç G, Costa S, Pásaro E, Laffon B, Teixeira JP. (2013): Neuronal cytotoxicity and genotoxicity induced by zinc oxide nanoparticles. Environ. Int.; 55: 92-100.

Villacorta L, Azzi A, Zingg JM. (2007): Regulatory role of vitamins $\mathrm{E}$ and $\mathrm{C}$ on extracellular matrix components of the vascular system. Mol. Aspects Med.; 28: 507-37.

Vandebriel RJ, De Jong WH. (2012): A review of mammalian toxicity of $\mathrm{ZnO}$ nanoparticles. Nanotechnol. Sci. Appl.; 5: 61-71.

Wang Y, Yuan L, Yao C, Ding L, Li C, Fang J, Sui K, Liu Y, Wu M.(2014): A combined toxicity study of zinc oxide nanoparticles and vitamin $\mathrm{C}$ in food additives. Nanoscale.; 6: 15333-42.

Wesselkamper SC, Chen LC, Gordon T. (2001): Development of pulmonary tolerance in mice exposed to zinc oxide fumes. Toxicol. Sci.; 60:144-151.

Wu G, Fang YZ, Yang S, Lupton JR, Turner ND. (2004): Glutathione metabolism and its implications for health. J. Nutr.; 134: 489-492.

Yang H, Liu C, Yang D, Zhang H, Xi Z. (2009): Comparative study of cytotoxicity, oxidative stress and genotoxicity induced by four typical nanomaterials: The role of particle size, shape and composition. J. Appl. Toxicol.; 29: 69-78.

Yousef OM, El-Rajhi WI. (2013): 
The Probable Protective Role of Vitamin C against Cyclosporine: an Induced Pulmonary Changes in Mice. J. Life Sci. Technol.;1: 1-6.

Zidan RA. (2011): Effect of long-term administration of amiodarone on rat lung and the possible protective role of vitamin $\mathrm{E}$ : A histological and immunohistochemical study. Egypt. J. of Histol.; 34:117-128. 


\section{دور حمض الأسكوربيك فى التسمم الرئوي الناجم عن جسيمات أكسبد الزنك النانوية ر في

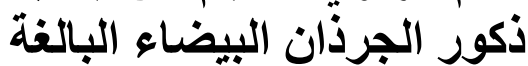

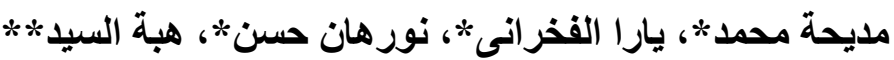

* قسم الطب الشرعى والسموم، **قسم الهستولوجى كلية الطب جامعة الزقازيق نورة

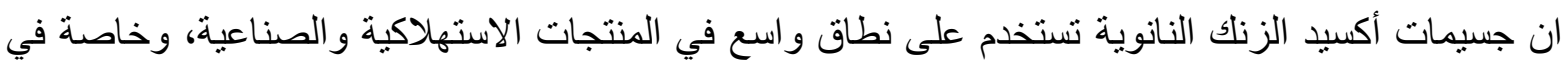

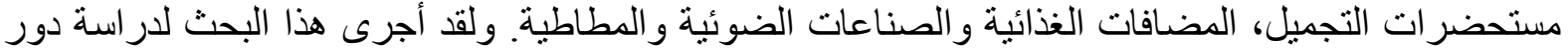

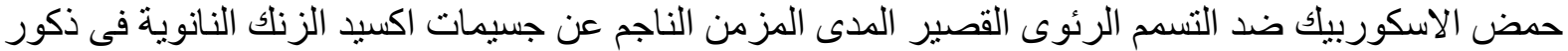

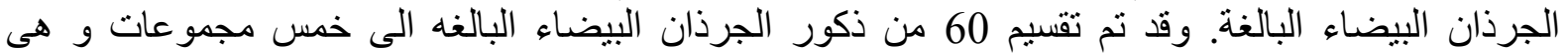

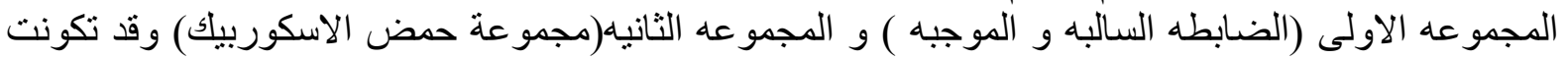

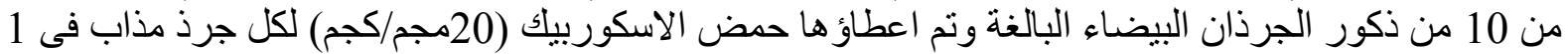

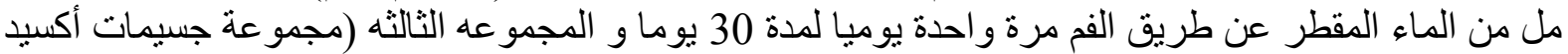

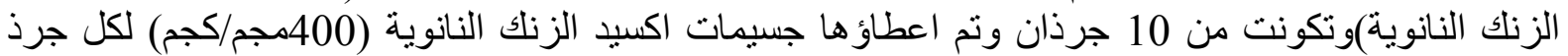

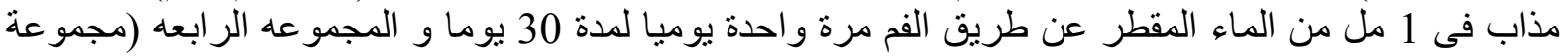

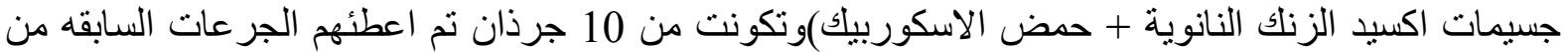

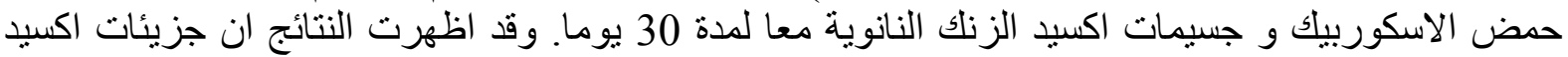

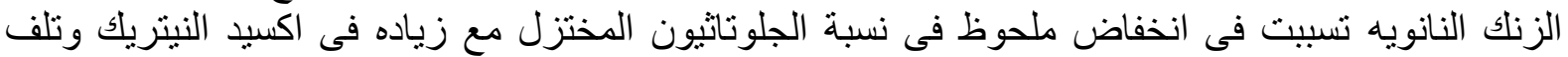

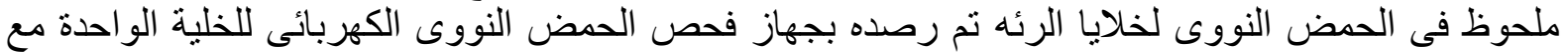

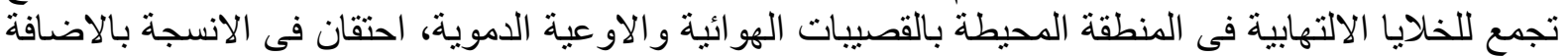

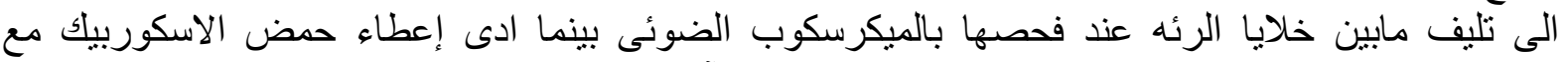

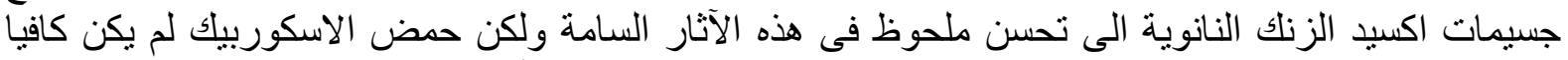

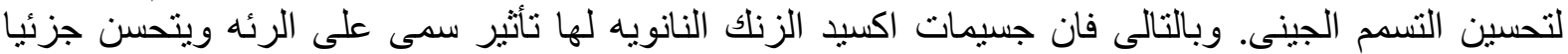

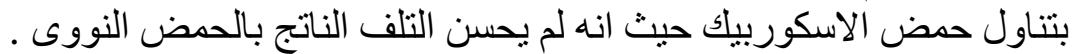

